\title{
Collaborative Problem Based Learning Integrated with Online Learning
}

\author{
https://doi.org/10.3991/ijet.v16i13.24159 \\ Endah Hendarwati $\left({ }^{\square}\right)$ \\ Universitas Negeri Surabaya, Surabaya, Indonesia \\ Universitas Muhammadiyah Surabaya, Surabaya, Indonesia \\ endah.17070996007@mhs.unesa.ac.id \\ Luthfiyah Nurlaela, Bachtiar Syaiful Bachri \\ Universitas Negeri Surabaya, Surabaya, Indonesia \\ Naili Sa'ida \\ Universitas Muhammadiyah Surabaya, Surabaya, Indonesia
}

\begin{abstract}
The development of science and technology during the Covid-19 pandemic requires universities to prepare their students to have collaborative and problem-solving skills through appropriate learning today, namely, integrating learning with online technology. This study aimed to determine the effectiveness of implementing collaborative problem-based learning (CPBL) integrated with online learning on student collaborative and problem-solving skills. The research method used was quantitative with a post-test quasi-experimental design involving fourth-semester students in the Early Childhood Education Study Program, Universitas Muhammadiyah Sidoarjo, Indonesia. The effectiveness of implementing CPBL integrated with online learning was analyzed primarily using the t-independent sample test. The study results showed that the implementation of CPBL integrated with online learning effectively improved students' collaborative and problem-solving skills. This effectiveness especially occurs when constructing knowledge, looking for resolution strategies, and evaluating solutions in breakout rooms and collaborative forums and zoom meetings. Meanwhile, the study results recommend that CPBL integrated with online learning can be used as a solution and an essential study for academics to keep familiarizing and practicing collaborative and problem-solving skills that are relatively difficult to improve during the Covid-19 pandemic.
\end{abstract}

Keywords - Online learning, technology integration, collaborative, problem solving

\section{Introduction}

The development of science and technology requires universities to produce graduates who have flexibility in solving problems collaboratively [1]. Many experts have put forward the importance of collaborative and problem-solving skills for college 
graduates. Real-life problem-solving abilities are essential and valuable in all fields of science [2]. The knowledge of the problem is an effort to find ways to overcome new problems faced [3]. Problem-solving needs to have high-level thinking by the insights someone has in solving problems [4].

Collaborative ability is the ability of someone who is involved in a team to solve a problem together. In solving these problems, each of them must understand the problem and be able to convey their ideas independently. Meanwhile, the collaborative is seen as an approach by combining cognitive and social problem-solving abilities through teamwork [5]. Collaborative can train students to work together in a group, construct participatory knowledge in making decisions, and conclude a problemsolving process [6]. Collaboration is a form of collaboration between individuals in the learning process to complement and assist the task completion process in producing the expected task completion [7]. Furthermore, the collaborative process is an adaptive system that respects all students' opinions, which can ultimately build a consensus [8]. Therefore, collaborative and problem-solving skills can be viewed as the ability to solve problems that are very important as social skills for students to organize the division of tasks in solving problems jointly.

The National Qualification Framework curriculum that applies in Indonesia also has the essence of the need for higher education graduates to have collaborative and problem-solving skills and is expected to apply and utilize science and technology in their fields [9], [10]. However, based on the PISA evaluation, it was found that students' collaborative skills in Indonesia were at the bottom of the list [11], [12]. In addition, many previous research results indicated that collaborative performance and problem solving for college graduates are inadequate. The survey results showed that college graduates still tend to take a long time to adjust to their work environment, even failing to collaborate with colleagues when solving urgent problems [13], [14]. In addition, students were often only required to have high learning outcomes, but students often fail to solve non-routine problems. In addition, lecturers ignored student collaborative skills as a knowledge construction process [15].

Thus we need learning that can facilitate collaborative skills and problem-solving students in tertiary institutions. In this study, the researcher constructed a new learning model called collaborative problem-based learning (CPBL). The integration of these two learning is to overcome the weaknesses of collaborative learning and problem-based learning [16]. The results of previous studies indicated that the integration of collaborative learning and problem-based learning had the potential to optimize students' collaborative and problem-solving skills [1], [5], [17]. In this study, CPBL is seen as collaborative learning carried out in groups that can reduce competition and feelings of individuals and each member in the group in achieving their goals and gaining new knowledge through collaborative problem-solving activities.

During the Covid 19 pandemic, various countries, including Indonesia, implemented online learning [18], [19]. Online learning is claimed to be used as a solution for implementing distance learning when a disaster or situation occurs, making it impossible to carry out direct learning. [20]. Online learning is defined as virtual learning activities organized by schools where the students and teachers are in separate locations. It requires the necessary media to support the learning process [21]. Learning 
activities that occur virtually emphasize the interaction and construction of online knowledge that facilitates the development of student understanding [22]. So that online learning makes learning easier from anywhere and anytime [23].

Through online learning, students can still meet face-to-face with friends and lecturers even though it is virtual, so it still looks like learning when offline. In addition, online learning also requires evaluation, such as offline learning to get improvements based on valid data [24]. Online learning makes use of the internet network in the learning process [25]. Online learning is an effort of online learning activities through internet networks using various platforms such as zoom meetings or google classrooms [26].

In this study, online learning was carried out using a zoom meeting platform. Zoom meeting is an application that provides video conferencing, online meetings, mobile collaboration, and chat services. In distance learning, zoom cloud meetings can present face-to-face learning through virtual environments. Learning activities through this platform can make students excited and actively involved in the learning process. The zoom platform has several features and better access compared to other platforms. The zoom meeting platform can present learning activities such as face-toface, even though it is done virtually. This application can be used by 1000 participants simultaneously. It has clear video and sound quality, various exciting features such as background and filter settings support presentation activities, an on-off feature for microphones and videos, and can be used to discuss small groups with breakout room settings [27].

Based on the explanations above, it is necessary to research integrating CPBL with online learning to achieve adequate collaborative and problem-solving skills for students in tertiary institutions. Therefore, this study was conducted to answer the formulation of the problem below.

1. How was the implementation of CPBL integrated with online learning?

2. Was CPBL integrated with online learning effectively to improve student collaborative skills?

3. Was CPBL integrated with online learning effectively to improve student problemsolving skills?

\section{Research Method}

\subsection{Research method}

The research method used was quantitative with a post-test quasi-experimental design. In this design, there were two class groups, namely the experimental class and the control class. The experimental class was a class that gets integrated CPBL implementation intervention with online learning. In contrast, the control class was a class that only got online learning implementation without being integrated with CPBL. The two groups received the same learning strategy each week for one semester in the even semester of the 2020-2021 University year. 


\subsection{Participants}

The sample involved consisted of 44 fourth semester students of the Early Childhood Education Study Program at the University of Muhammadiyah Sidoarjo, Indonesia. The sample was determined by random sampling technique on population. It was done to provide equal opportunities and opportunities for students to participate in research [28].

\subsection{Instrument and data analysis}

The instruments used were collaborative questionnaires and problem-solving tests. The collaborative questionnaire aimed to obtain data on student collaborative skills that are formed during learning. This questionnaire had a total of 15 items of student perception statements regarding collaborative elements, which consisted of group collaboration, multi-way interactions, and group decision making [29]. In addition, this collaborative questionnaire was filled based on a Likert scale with four choices, namely strongly agree, agree, disagree, and strongly disagree. Meanwhile, the problem-solving test aimed to obtain data on student problem-solving skills after learning. This test had five essay questions regarding the stages of problem-solving on the topic of educator decision-making regarding selecting learning strategies that consist of understanding problems, looking for resolution strategies, implementing settlement strategies, and evaluating solutions [30].

Data analysis included homogeneity test, normality test, and independent sample ttest using SPSS version 20.0. The homogeneity test aimed to measure the variance differences between the experimental and control classes. The experimental and control classes were said to be homogeneous if the significance value $>0.05$. Meanwhile, the normality test aimed to measure the normal distribution of data in the experimental and control classes. Data in the experimental and control classes were normal, if the significance value $>0.05$ through the Kolmogorov-Smirnov test and ShapiroWilk test. The t-independent sample test aimed to measure the effectiveness of the implementation of CPBL, which was integrated with online learning. The implementation of integrated CPBL with online learning was said to be effective if the significance value (2-tailed) $>0.05[31]$.

\section{$3 \quad$ Results and Discussion}

\subsection{CPBL implementation was integrated with online learning}

In this study, the CPBL stage was constructed from collaborative learning and problem-based learning. Then the construction of the CPBL stages was then integrated with the characteristics of online learning activities. The CPBL stages were integrated with online learning (See Table 1), which was carried out through a zoom meeting platform consisting of problem orientation, collaborative problem-solving 
activities, presentations and discussions, advanced problem solving, and evaluation [24], [32], [33].

Table 1. CPBL stages were integrated with online learning

\begin{tabular}{|l|l|}
\hline \multicolumn{1}{|c|}{ Stages } & \multicolumn{1}{c|}{ Learning Activities } \\
\hline $\begin{array}{l}\text { Motivation and problem } \\
\text { orientation }\end{array}$ & $\begin{array}{l}\text { Lecturers motivated students to generate interest in learning, explained learning } \\
\text { objectives, provided explanations about learning, and provided stimulus to initial } \\
\text { problems by learning objectives. }\end{array}$ \\
\hline $\begin{array}{l}\text { Collaborative problem- } \\
\text { solving } \\
\text { activities }\end{array}$ & $\begin{array}{l}\text { Lecturers form student groups or teams and provided problems that must be } \\
\text { solved collaboratively. Collaborative in this case was the occurrence of multi- } \\
\text { directional interactions between lecturers and students, students and students in } \\
\text { groups in the breakout room, and students with other students outside the group } \\
\text { through time-sharing and opportunities at zoom meetings. }\end{array}$ \\
\hline $\begin{array}{l}\text { Presentation and discus- } \\
\text { sion }\end{array}$ & $\begin{array}{l}\text { Lecturers guided students per group in presenting the results of solving their } \\
\text { problems through classical zoom meetings. }\end{array}$ \\
\hline $\begin{array}{l}\text { Advanced Trouble- } \\
\text { shooting }\end{array}$ & $\begin{array}{l}\text { The lecturer gave an unstructured follow-up problem similar to the previous one, } \\
\text { but had a higher weight in the breakout room, then returned to the formal forum } \\
\text { zoom meeting. }\end{array}$ \\
\hline Evaluation & $\begin{array}{l}\text { The lecturer guides students in evaluating the problem-solving process that had } \\
\text { been solved previously. }\end{array}$ \\
\hline
\end{tabular}

\subsection{The effectiveness of CPBL implementation was integrated with online learning on collaborative skills}

Before measuring the implementation of integrated CPBL with online learning, it is effective against student collaborative skills. Data homogeneity (See Table 2) and data normality (See Table 3) were analyzed from collaborative skills data in this study.

Table 2. Homogeneity test of data variance on collaborative skills

\begin{tabular}{|l|l|c|c|c|c|}
\hline \multicolumn{2}{|c|}{} & Levene Statistic & df1 & df2 & Sig. \\
\hline \multirow{4}{*}{$\begin{array}{l}\text { Collaborative } \\
\text { values }\end{array}$} & Based on Mean & 0.145 & 1 & 42 & 0.705 \\
\cline { 2 - 6 } & Based on Median & 0.112 & 1 & 42 & 0.740 \\
\cline { 2 - 6 } & Based on Median and with adjusted df & 0.112 & 1 & 40.728 & 0.740 \\
\cline { 2 - 6 } & Based on trimmed mean & 0.141 & 1 & 42 & 0.709 \\
\hline
\end{tabular}

Table 3. Normality test of collaborative skills data

\begin{tabular}{|l|c|c|c|c|c|c|}
\hline & \multicolumn{3}{|c|}{ Kolmogorov-Smirnov $^{\text {a }}$} & \multicolumn{3}{c|}{ Shapiro-Wilk } \\
\cline { 2 - 7 } & Statistic & $\boldsymbol{d f}$ & Sig. & Statistic & $\boldsymbol{d f}$ & Sig. \\
\hline Collaborative values & 0.114 & 44 & 0.180 & 0.958 & 44 & 0.107 \\
\hline
\end{tabular}

a. Lilliefors Significance Correction

In Table 2, it was found that the homogeneity of Lavene was 0.145 with a significance value of 0.705 . It could be said that the experimental and control groups had homogeneity in student collaborative skills data. In Table 3, the significance value (pvalue) $>0.05$ with the Kolmogorov-Smirnov test value was 0.114 and the ShapiroWilk test value was 0.107 . That is, it can be said that the collaborative skills data were 
normally distributed. Because the data on collaborative skills have met the criteria for the homogeneity and normality test, an independent sample t-test can be carried out.

Table 4. Group Statistics on collaborative skills data

\begin{tabular}{|l|l|c|c|c|c|}
\hline & \multicolumn{1}{|c|}{ Classes } & N & Mean & Std. Deviation & Std. Error Mean \\
\hline \multirow{2}{*}{ Collaborative values } & Experiment & 23 & 90.0000 & 4.79583 & 1.00000 \\
\cline { 2 - 6 } & Control & 21 & 67.9524 & 5.40811 & 1.18015 \\
\hline
\end{tabular}

Table 5. Independent samples test on collaborative skills data

\begin{tabular}{|c|c|c|c|c|c|c|c|c|c|}
\hline & \multicolumn{2}{|c|}{$\begin{array}{l}\text { Levene's Test } \\
\text { for Equality of } \\
\text { Variances }\end{array}$} & \multicolumn{7}{|c|}{ t-test for Equality of Means } \\
\hline & \multirow[t]{2}{*}{$\boldsymbol{F}$} & \multirow[t]{2}{*}{ Sig. } & \multirow[t]{2}{*}{$t$} & \multirow[t]{2}{*}{$d f$} & \multirow[t]{2}{*}{$\begin{array}{c}\text { Sig. } \\
\text { (2-tailed) }\end{array}$} & \multirow[t]{2}{*}{$\begin{array}{c}\text { Mean } \\
\text { Difference }\end{array}$} & \multirow[t]{2}{*}{$\begin{array}{c}\text { Std.Error } \\
\text { Difference }\end{array}$} & \multicolumn{2}{|c|}{$\begin{array}{l}95 \% \text { Confidence } \\
\text { Interval of the } \\
\text { Difference }\end{array}$} \\
\hline & & & & & & & & Lower & Upper \\
\hline $\begin{array}{l}\text { Equal variances } \\
\text { assumed }\end{array}$ & \multirow{2}{*}{0.145} & \multirow{2}{*}{0.705} & 14.333 & 42 & 0.000 & 22.04762 & 1.53826 & 18.94328 & 25.15196 \\
\hline $\begin{array}{l}\text { Equal variances } \\
\text { not assumed }\end{array}$ & & & 14.253 & 40.194 & 0.000 & 22.04762 & 1.54685 & 18.92179 & 25.17345 \\
\hline
\end{tabular}

Table 4 and Table 5 found that the equal variance was assumed with a sig (2-tailed) value of $0.000>0.05$. It means that the experimental and control classes had a significant difference in the post-test scores of collaborative skills. In other words, it can be concluded that the implementation of integrated CPBL with online learning is effective for improving student collaborative skills.

\subsection{The effectiveness of CPBL implementation was integrated with online learning on problem-solving skills}

Before measuring integrated CPBL with online learning, it is effective against students' problem-solving skills. The data homogeneity (See Table 6) and data normality (See Table 7) were analyzed from data on problem-solving skills in this study.

Table 6. Homogeneity test of data variance problem-solving skills

\begin{tabular}{|l|l|c|c|c|c|}
\hline \multicolumn{2}{|c|}{} & Levene Statistic & df1 & df2 & Sig. \\
\hline \multirow{3}{*}{$\begin{array}{l}\text { Problem } \\
\text { solving } \\
\text { values }\end{array}$} & Based on Mean & 0.404 & 1 & 42 & 0.529 \\
\cline { 2 - 6 } & Based on Median & 0.385 & 1 & 42 & 0.539 \\
\cline { 2 - 6 } & Based on Median and with adjusted df & 0.385 & 1 & 41.979 & 0.539 \\
\cline { 2 - 6 } & Based on trimmed mean & 0.409 & 1 & 42 & 0.526 \\
\hline
\end{tabular}


Table 7. Normality test of problem-solving skills data

\begin{tabular}{|l|c|c|c|c|c|c|}
\hline \multirow{2}{*}{} & \multicolumn{4}{|c|}{ Kolmogorov-Smirnov ${ }^{\mathrm{a}}$} & \multicolumn{3}{c|}{ Shapiro-Wilk } \\
\cline { 2 - 7 } & Statistic & $\boldsymbol{d f}$ & Sig. & Statistic & $\boldsymbol{d f}$ & Sig. \\
\hline Problem solving values & 0.095 & 44 & $0.200^{*}$ & 0.980 & 44 & 0.639 \\
\hline
\end{tabular}

a. Lilliefors Significance Correction

In Table 6, it was found that the homogeneity of Lavene was 0.404 with a significance value of 0.529 . It could be said that the experimental and control groups had homogeneity in the data on student problem-solving skills. In Table 7, the significance value ( $\mathrm{p}$-value) $>0.05$ with the Kolmogorov-Smirnov test value was 0.095 and the Shapiro-Wilk test value was 0.639. That was, it can be said that the problemsolving skills data were normally distributed. Because the data on problem-solving skills have met the criteria for the homogeneity and normality test, an independent sample t-test can be done.

Table 8. Group Statistics on problem-solving skills data

\begin{tabular}{|l|l|l|l|l|l|}
\hline & Classes & \multicolumn{1}{|c|}{$\mathbf{N}$} & Mean & Std. Deviation & Std. Error Mean \\
\hline \multirow{2}{*}{ Problem solving values } & Experiment & 23 & 84.4783 & 4.52136 & 0.94277 \\
\cline { 2 - 6 } & Control & 21 & 63.7143 & 3.19598 & 0.69742 \\
\hline
\end{tabular}

Table 9. Independent samples test on problem-solving data

\begin{tabular}{|c|c|c|c|c|c|c|c|c|c|}
\hline & \multicolumn{2}{|c|}{$\begin{array}{c}\text { Levene's Test for } \\
\text { Equality of } \\
\text { Variances }\end{array}$} & \multicolumn{7}{|c|}{ t-test for Equality of Means } \\
\hline & \multirow[t]{2}{*}{$\boldsymbol{F}$} & \multirow[t]{2}{*}{ Sig. } & \multirow[t]{2}{*}{$t$} & \multirow[t]{2}{*}{$d f$} & \multirow[t]{2}{*}{$\begin{array}{c}\text { Sig. } \\
\text { (2-tailed) }\end{array}$} & \multirow[t]{2}{*}{$\begin{array}{c}\text { Mean } \\
\text { Difference }\end{array}$} & \multirow{2}{*}{\begin{tabular}{|c|} 
Std. \\
Error \\
Differe \\
nce
\end{tabular}} & \multicolumn{2}{|c|}{$\begin{array}{l}95 \% \text { Confidence } \\
\text { Interval of the } \\
\text { Difference }\end{array}$} \\
\hline & & & & & & & & Lower & Upper \\
\hline $\begin{array}{l}\text { Equal variances } \\
\text { assumed }\end{array}$ & \multirow{2}{*}{2.698} & \multirow{2}{*}{0.108} & 17.434 & 42 & 0.000 & 20.76398 & 1.19104 & 18.36037 & 23.16759 \\
\hline $\begin{array}{l}\text { Equal variances } \\
\text { not assumed }\end{array}$ & & & 17.706 & 39.617 & 0.000 & 20.76398 & 1.17269 & 18.39316 & 23.13479 \\
\hline
\end{tabular}

Table 8 and Table 9 found that the equal variance was assumed with a sig (2-tailed) value of $0.000>0.05$. It means that the experimental and control classes had a significant difference in the post-test scores of problem-solving skills. In other words, it can be concluded that the implementation of integrated CPBL with online learning is effective for improving student problem-solving skills.

\section{Discussion}

The findings of this study were that the implementation of integrated CPBL with online learning could improve student collaborative skills. This finding was in line with previous studied that online learning, while paying attention to the aspects of cooperation that results in interactions between individuals, supports each other, and 
facilitates each other between educators and students [34], will improve and enhance student collaborative skills [35], [36]. In addition, online learning, including during the Covid-19 pandemic, which applies constructivist principles, will encourage students to become active learners, able to learn independently, collaboratively, and contextually [37], [38]. Online learning also still allows a student's zone of proximal development (ZPD) to develop according to its stages [39].

Another finding was that the implementation of integrated CPBL with online learning could improve students' problem-solving skills. This finding was in line with previous studied that even during the Covid-19 pandemic, effective student problemsolving skills can gradually increase if students are trained in non-routine problemsolving activities during online learning [40]-[42]. Online learning can produce adequate student problem-solving skills, as long as the learning design can accommodate student decision-making activities in planning strategies and evaluating solutions [19], [24].

The effectiveness of increasing student collaborative skills and problem-solving is obtained through integrated CPBL stages with online learning in motivation and problem orientation, collaborative problem-solving activities, presentations and discussions, advanced problem solving, and evaluation [24], [32], [33]. Learning stages that accommodate collaboration opportunities to solve problems when online learning in breakout rooms and zoom meeting forums make knowledge construction and group decision making develop during problem-solving activities [35], [38]. In other words, the building of online learning through a zoom meeting platform that is integrated with the CPBL stages is considered successful. It can be used as a recommendation for academics to familiarize themselves and practice collaborative and problemsolving skills that are relatively difficult to improve during the Covid-19 pandemic.

\section{Conclusion}

Based on the results and discussion, this study concluded that implementing integrated CPBL with online learning was effective for improving collaborative and problem-solving skills for students at the tertiary level during the Covid-19 pandemic. This effectiveness was obtained through integrated CPBL stages with online learning in motivation and problem orientation, collaborative problem-solving activities, presentations and discussions, advanced problem solving, and evaluation. This effectiveness primarily occurs when constructing knowledge, looking for resolution strategies, and evaluating solutions in breakout rooms and collaborative forums and zoom meetings. Therefore, this study recommends that CPBL integrated with online learning can be an essential solution and research for academics interested in distance learning studies. It focuses on students' higher education skills and achieving learning outcomes, especially in studies that focus on maintaining and practicing collaborative and problem-solving skills during the Covid-19 pandemic. 


\section{References}

[1] Y. Song, "Improving primary students' collaborative problem solving competency in project-based science learning with productive failure instructional design in a seamless learning environment," Educ. Technol. Res. Dev., vol. 66, no. 4, pp. 979-1008, 2018. https://doi.org/10.1007/s11423-018-9600-3

[2] S. Fadillah, "Kemampuan Pemecahan Masalah Matematis dalam. Pembelajaran Matematika," Pros. Semin. Nas. Penelit., 2009.

[3] G. Polya, How to Solve It. New Jersey: Princeton University Press, 2004.

[4] H. Ulya, "Profil Kemampuan Pemecahan Masalah Siswa Bermotivasi Belajar Tinggi Berdasarkan Ideal Problem Solving," J. Konseling Gusjigang, vol. 2, no. 1, pp. 90-96, 2016. https://doi.org/10.24176/jkg.v2i1.561

[5] P. Care, E. \& Griffin, "Approach to assessment of collaborative problem solving.," Res. Pract. Technol. Enhanc. Learn., vol. 9, no. 3, pp. 367-388, 2014.

[6] V. Sporea, A., Sporea, \& Păiş, "A collaborative platform for science teaching at elementary and middle school level," vol. 4, no. 1, pp. 1-7, 2015. https://doi.org/10.11648 /j.ijeedu.20150401.11

[7] K. E. Murti, "Pendidikan Abad 21 dan Implementasinya pada Pembelajaran Di Sekolah Menengah Kejuruan (SMK) untuk Paket Keahlian Desain Interior," Artik. Kurikulum 2013 SMK, pp. 1-23. https://doi.org/10.31227/osf.io/hynr8

[8] A. Ansell, C. dan Gash, "Collaborative Governance in Theory and Practice, Journal of Publik Administration Research and Theory," 2007.

[9] M. Nuh, "Peraturan Mentri Pendidikan dan Kebudayaan Republik Indonesia No 69 Tahun 2013 Tentang Kerangka Dasar Struktur Kurikulum Sekolah Menengah Atas /Madrasah Aliyah," Peratur. Pemerintah Republik Indones. No 69 Tahun 2013, pp. 1-253, 2013. https://doi.org/10.31219/osf.io/xtdba

[10] A. Rahmawati, N. Suryani, M. Akhyar, and Sukarmin, "Developing Self-Assessment Instrument for Measuring Pre-Service Teachers' Technological Pedagogical Vocational Knowledge," Humanit. Soc. Sci. Rev., vol. 8, no. 3, pp. 676-685, 2020. https://doi.org/10. 18510/hssr.2020.8372

[11] A. H. Dewantara, Zulkardi, and Darmawijoyo, "Assessing Seventh Graders , Mathematical Literacy in Solving PISA-like tasks.," J. Math. Educ., vol. 6, no. 2, pp. 3949, 2013. https://doi.org/10.22342/jme.6.2.2163.117-128

[12] OECD, PISA 2015 Assessment and Analytical Framework. Paris: OECD, 2017.

[13] H. Z. Baloch, A. Abdul Rahman, and N. A Ihad, "Mobile Collaborative Informal Learning Design: Study of collaborative effectiveness using Activity Theory," Int. J. Interact. Mob. Technol., vol. 6, no. 3, p. 34, 2012. https://doi.org/10.3991/ijim.v6i3.2090

[14] N. D. Handayani, I. B. N. Mantra, and I. N. Suwandi, "Integrating collaborative learning in cyclic learning sessions to promote students' reading comprehension and critical thinking," Int. Res. J. Manag. IT Soc. Sci., vol. 6, no. 5, pp. 303-308, Sep. 2019. https://doi.org/10. 21744/irjmis.v6n5.777

[15] J. Nookhong and P. Wannapiroon, "Development of Collaborative Learning Using Casebased Learning via Cloud Technology and Social Media for Enhancing Problem-solving Skills and ICT Literacy within Undergraduate Students," Procedia - Soc. Behav. Sci., vol. 174, no. 2, pp. 2096-2101, 2015. https://doi.org/10.1016/j.sbspro.2015.02.007

[16] C. J. Huang and Y. T. Chuang, "Supporting the development of collaborative problembased learning environments with an intelligent diagnosis tool," Expert Syst. Appl., vol. 35, no. 3, pp. 622-631, 2008. https://doi.org/10.1016/j.eswa.2007.07.028 
[17] F. Hesse, E. Care, J. Buder, K. Sassenberg, and P. Griffin, "A Framework for Teachable Collaborative Problem Solving Skills," in Assessment and Teaching of 21st Century Skills, Dordrecht: Springer Netherlands, 2015, pp. 37-56. https://doi.org/10.1007/978-94-017-93 $\underline{95-7 \_2}$

[18] N. M. Almusharraf and S. H. Khahro, "Students' Satisfaction with Online Learning Experiences during the COVID-19 Pandemic," Int. J. Emerg. Technol. Learn., vol. 15, no. 21, pp. 246-267, 2020. https://doi.org/10.3991/ijet.v15i21.15647

[19] R. Firmansyah, D. M. Putri, M. G. S. Wicaksono, S. F. Putri, A. A. Widianto, and M. R. Palil, "Educational Transformation: An Evaluation of Online Learning Due To COVID19," Int. J. Emerg. Technol. Learn., vol. 16, no. 07, p. 61, 2021. https://doi.org/10.3991/ ijet.v16i07.21201

[20] A. S. Syarifudin, "Implementasi Pembelajaran Daring Untuk Meningkatkan Mutu Pendidikan Sebagai Dampak Diterapkannya Social Distancing," J. Pendidik. Bhs. dan Sastra Indones., 2020. https://doi.org/10.21107/metalingua.v5i1.7072

[21] A. N. Sobron and R. Bayu, "Persepsi Siswa dalam Studi Pengaruh Daring Learning terhadap Minat Belajar IPA," Pendidik. Islam dan Multikulturalisme, vol. 1, no. 2, pp. 3038, 2019. https://doi.org/10.37680/scaffolding.v1i2.117

[22] M. F. Amir, N. Ariyanti, N. Anwar, E. Valentino, and D. S. N. Afifah, “Augmented Reality Mobile Learning System : Study to Improve PSTs' Understanding of Mathematical Development," Int. J. Interact. Mob. Technol., vol. 14, no. 9, pp. 239-247, 2020. https:// doi.org/10.3991/ijim.v14i09.12909

[23] S. Sumarmi, S. Bachri, L. Y. Irawan, M. Aliman, and W. I. Wan Ahmad, "Project-Based Research Learning (PBRL) Integrated With E-Learning in Projects Completion," Int. J. Emerg. Technol. Learn., vol. 16, no. 07, p. 16, 2021. https://doi.org/10.3991/ijet.v16i07.21 $\underline{193}$

[24] N. Ramlee, M. S. Rosli, and N. S. Saleh, "Mathematical HOTS cultivation via online learning environment and 5E inquiry model: Cognitive impact and the learning activities," Int. J. Emerg. Technol. Learn., vol. 14, no. 24, pp. 140-151, 2019. https://doi.org/10.3991/ ijet.v14i24.12071

[25] M. Isman, "Pembelajaran Media dalam Jaringan (Moda Jaringan)," Progress. Fun Educ. Semin., 2016.

[26] Y. Bilfaqih, Esensi Pengembangan Pembelajaran Daring. Yogyakarta: Deepublish, 2015.

[27] U. K. Syarif Hidayatullah, "Implementasi Model Kesuksesan Sistem Informasi DeLone And McLean Terhadap Sistem Pembelajaran Berbasis Aplikasi Zoom Di Saat Pandemi Covid-19," J. Teknol. dan Manaj. Inform., vol. 6, no. 1, p. 45, 2020. https://doi.org/10. 26905/jtmi.v6i1.4165

[28] H. Taherdoost, "Sampling Methods in Research Methodology; How to Choose a Sampling Technique for Research," Int. J. Acad. Res. Manag., vol. 5, p. 02546796, 2016. https:// doi.org/10.2139/ssrn.3205035

[29] Y. C. Yeh, "Integrating collaborative PBL with blended learning to explore preservice teachers' development of online learning communities," Teach. Teach. Educ., vol. 26, no. 8, pp. 1630-1640, 2010. https://doi.org/10.1016/j.tate.2010.06.014

[30] G. Polya, How to Solve it? Princeton, NJ: Princeton University Press, 1945.

[31] J. M. Bland and D. G. Altman, "Statistics notes: Cronbach's alpha," BMJ, vol. 314, no. 7080, pp. 572-572, Feb. 1997. https://doi.org/10.1136/bmj.314.7080.572

[32] R. I. Arends, Learning to teach; 9th Edition. New York: Mc. Graw -Hil, 2012.

[33] E. F. Barkley, K. P. Cross, and C. H. Major, Collaborative learning techniques: A handbook for college faculty. San Francisco: Jossey-Bass Publishers, 2005.

[34] M. Laal, "Positive Interdependence In collaborative learning. Procedia.," 2013. 
[35] H. Le, J. Janssen, and T. Wubbels, "Collaborative learning practices: teacher and student perceived obstacles to effective student collaboration," Cambridge J. Educ., vol. 48, no. 1, pp. 103-122, Jan. 2018. https://doi.org/10.1080/0305764x.2016.1259389

[36] F. Qing and L. Li, "Web-Based Collaborative Learning," Procedia Environ. Sci., vol. 11, pp. 189-192, 2011.

[37] H. H. B. Dalimunthe, A. Sutisna, L. Zakiah, and S. Handayani, "Transformative science education: Empowering self-regulated learners during pandemic COVID-19," 2021, p. 050022. https://doi.org/10.1063/5.0041666

[38] A. Blackburn and D. Hewitt, "Fostering creativity and collaboration in a fully online tertiary music program," Int. J. Innov. Online Educ., vol. 4, no. 2, 2020. https://doi.org/10. 1615/intjinnovonlineedu.2020035099

[39] T. Fani and F. Ghaemi, "Implications of Vygotsky's Zone of Proximal Development (ZPD) in Teacher Education: ZPTD and Self-scaffolding," Procedia - Soc. Behav. Sci., vol. 29, pp. 1549-1554, 2011. https://doi.org/10.1016/j.sbspro.2011.11.396

[40] B. K. Prahani et al., "ORNE Learning Model to Improve Problem-Solving Skills of Physics Bachelor Candidates: An Alternative Learning in the Covid-19 Pandemic," $J$. Penelit. Fis. dan Apl., vol. 10, no. 1, p. 71, 2020. https://doi.org/10.26740/jpfa.v10n1.p71$\underline{80}$

[41] Y.-W. Lin, C.-L. Tseng, and P.-J. Chiang, "The Effect of Blended Learning in Mathematics Course," EURASIA J. Math. Sci. Technol. Educ., vol. 13, no. 3, Dec. 2016.

[42] C. Coman, L. G. Țîru, L. Meseșan-Schmitz, C. Stanciu, and M. C. Bularca, "Online Teaching and Learning in Higher Education during the Coronavirus Pandemic: Students' Perspective," Sustainability, vol. 12, no. 24, p. 10367, Dec. 2020. https://doi.org/10.3390 $\underline{\text { Isu122410367 }}$

\section{$7 \quad$ Authors}

Endah Hendarwati is a lecturer in the Universitas Muhammadiyah Surabaya. She is also currently pursuing a doctoral program at Universitas Negeri Surabaya, Indonesia. Her main research interest areas are technological innovation and learning.

Luthfiyah Nurlaela is a lecturer in the education technology study program at the Universitas Negeri Surabaya, Indonesia. Her main research interest area is learning strategies.

Bachtiar Syaiful Bachri is a lecturer in the educational technology study program, Universitas Negeri Surabaya, Indonesia. His main research interest areas are curriculum and instruction.

Naili Sa'ida is a lecturer in the early childhood education study program, Universitas Muhammadiyah Surabaya, Indonesia. Her main research interest areas are technology education.

Article submitted 2021-04-24. Resubmitted 2021-05-23. Final acceptance 2021-05-24. Final version published as submitted by the authors. 